\title{
Adherence to treatment: practice, education and research in Danish community pharmacy
}

\author{
Lotte S. HAUGBØLLE, Hanne HERBORG. \\ Received (first version): 25-Oct-2009 Accepted: 8-Dec-2009
}

\begin{abstract}
${ }^{*}$
Objective: To describe the practice, education and research concerning medication adherence in Danish community pharmacy.

Methods: The authors supplemented their expertise in the area of medication adherence through their contacts with other educators and researchers as well as by conducting searches in the Danish Pharmacy Practice Evidence Database, which provides annually updated literature reviews on intervention research in Danish pharmacy practice. Results: Practice: Medication adherence is the focus of and/or is supported by a large number of services and initiatives used in pharmacy practice such as governmental funding, IT-supported medicine administration systems, dose-dispensing systems, theme years in pharmacies on adherence and concordance, standards for counselling at the counter, pharmacist counselling, medication reviews and inhaler technique assessment. Education: In Denmark, pharmacy and pharmaconomist students are extensively trained in the theory and practice of adherence to therapy.

Pharmacy staff can choose from a variety of continuing education and post-graduate programmes which address patient adherence. Research: Nine ongoing and recently completed studies are described. Early research in Denmark comprised primarily smaller, qualitative studies centred on user perspectives, whereas later research has shifted the focus towards larger, quantitative, controlled studies and action-oriented studies focusing on patient groups with chronic diseases (such as diabetes, asthma, coronary vascular diseases).

Conclusions: Our analysis has documented that Danish pharmaceutical education and research has focused strongly on adherence to treatment for more than three decades. Adherence initiatives in Danish community pharmacies have developed substantially in the past 5-10 years, and, as
\end{abstract}

*Lotte S. HAUGBØLLE. PhD(pharm). Associate Professor. Faculty of Pharmacy, Department of Pharmacology and Pharmacotherapy . Copenhagen University. Copenhagen (Denmark).

Hanne HERBORG. MSc (pharm). Director R\&D, Pharmakon. Hillerød (Denmark).

Series editors:

Marie P. SCHNEIDER. PhD. Researcher and lecturer in Pharmacy Practice. Community Pharmacy, Dpt of ambulatory care and community medicine, University Hospital, Lausanne (Switzerland).

Parisa ASLANI. PhD. Senior Lecturer in Pharmacy

Practice. Faculty of Pharmacy, University of Sydney (Australia). pharmacies have prioritised their role in health care and patient safety, this development can be expected to continue in future years.

Keywords: Medication Adherence. Pharmacists. Denmark.

\section{CUMPLIMIENTO: REVISIÓN DE LA EDUCACIÓN, INVESTIGACIÓN, PRÁCTICA Y POLÍTICA EN ESPAÑNA}

\section{RESUMEN}

Objetivo: Describir la práctica, educación e investigación relativa a cumplimiento de la medicación en la farmacia comunitaria danesa. Métodos: Los autores complementaron su experiencia en el área del cumplimiento de la medicación mediante sus contactos con otros educadores e investigadores así como mediante búsquedas en la Base de Datos de Evidencia en Farmacia Práctica Danesa, que proporciona anualmente revisiones de la literatura sobre investigaciones de intervención en la farmacia práctica danesa.

Resultados: Práctica: El cumplimiento de la medicación es el centro de y/o esta incluida en un gran número de servicios e iniciativas utilizadas en la farmacia práctica tales como financiación gubernamental, sistemas de administración de medicamentos electrónicos, sistemas de dispensación de dosis, temas en farmacias sobre cumplimiento y concordancia, estándares de consejo en el mostrador, consejo farmacéutico, revisión de la medicación, y evaluación de la técnica de inhalación. Educación: en Dinamarca, los estudiantes de farmacia y técnicos de farmacia son formados intensamente en teoría y práctica de cumplimiento terapéutico. El personal de la farmacia puede elegir entre una variedad de formación continuada y programas postgraduados que tratan del cumplimiento del paciente. Investigación: Se describen nueve estudios en marcha o concluidos. Las primeras investigaciones en Dinamarca comprendieron fundamentalmente estudios pequeños, cualitativos y centrados en las perspectivas del usuario, mientras que las últimas investigaciones mudaron su ámbito hacia estudios mayores, cuantitativos, controlados y estudios de acción-orientada que se centraban en grupos de pacientes con enfermedades crónicas (como diabetes, asma, enfermedad coronaria). Conclusión: Nuestra investigación ha documentado que la educación y la investigación farmacéuticas danesas se han centrado fuertemente en el cumplimiento del tratamient durante más de tres 
décadas. Las iniciativas sobre cumplimiento en las farmacias comunitarias danesas se desarrollaron sustancialmente en los pasados 5-10 años y, como las farmacias han priorizado su papel en los cuidados de salud y en la seguridad del paciente, puede esperarse que este desarrollo continúe en los próximos años.

Palabras clave: Adherencia a la medicación. Farmacéuticos. Dinamarca.

\section{INTRODUCTION}

The consequences of poor adherence to long-term therapies include poor health outcomes and increased health care costs. Adherence can be defined as “... the extent to which a person's behaviour - taking medication, following a diet and/or lifestyle changes, corresponds with agreed recommendations from a health care practitioner". 1,2

This article describes the initiatives taken in the Danish primary health care sector, specifically community pharmacy, concerning medication adherence practice, education and research.

\section{METHODS}

The information concerning policy and practice is based firstly on the authors' extensive knowledge, and secondly, on a mapping of pharmacy practice activities in Nordic countries conducted in 2008 for the Nordic Pharmacy Association. ${ }^{3}$

The results in the research section are based on searches in 1) the Danish Pharmacy Practice Evidence Database and 2) PubMed. The Danish Pharmacy Practice Evidence Database has been developed and is operated and annually updated by Pharmakon (the Danish College of Pharmacy Practice- www.pharmakon.com). It is an electronic searchable database, comprising literature reviews (published in English and Scandinavian languages) and Danish reports in key pharmacy practice areas, with emphasis on primary care. ${ }^{4,5}$ The following keywords were used in the Pubmed search: (compliance OR adherence OR concordance) AND (intervention* OR (clinical trial)) AND medication or medicines or drugs AND ((primary care) or (pharmacist OR pharmacists OR pharmacy OR pharmacies).As a second strategy, input was sought from researchers in key organizations: Pharmakon, Association of Danish Pharmacies, and the Faculty of Pharmaceutical Sciences.

\section{RESULTS AND DISCUSSION}

\section{Danish community pharmacy practice}

In 2007 Denmark's population of 5.5 million spent approximately EUR 550 per inhabitant on medicines. ${ }^{6}$ Community pharmacies in Denmark are privately owned, but as they are an important part of the health care system, the state closely regulates their premises, tasks, competency requirements, prices and profit margins All Danish pharmacies are members of the Association of Danish Pharmacies. Pharmaconomists (formerly referred to as pharmacy assistants) may dispense prescriptions and advise customers in a pharmacy. ${ }^{6}$

\section{Adherence standards and guidelines}

Community pharmacies in Denmark play a key role in providing the public with information and counselling in the use of medicines, self-care and disease prevention. They provide medicines and medicine-related services in accordance with national laws and regulations, the WHO-approved Guidelines for Good Pharmacy Practice and Danish quality standards for pharmacies.

At present, there are no official Danish adherence policies on medication non-adherence. However, medication is a key topic in The Strategy for Chronic Conditions. ${ }^{7}$ The strategy, which focusses on the organisation and provision of health care and on patient self-management is currently being implemented at regional level. Moreover, the Danish Society for Patient Safety has developed medication safety strategies in which adherence is a focus, and which is expected to attract more attention in the future. 8

The Association of Danish Pharmacies launched its "Standard for Counselling at the Counter" in $2007 .{ }^{7}$ The standard sets out three different levels for counselling at the counter: A 'basic', 'extended' and an 'advanced' level. At the basic level, the standard requires pharmacy staff to invite all customers purchasing medicines for themselves to a 'dialogue', by asking questions and giving information about the medicine. At the extended level, the pharmacy staff should, in addition, ask questions about customers' specific risks and provide relevant counselling according to the customer's needs. At the advanced level, pharmacy staff is required to also assess symptoms and identify 'alarm signals' in order to help the customer prevent medicine-related problems. Pseudocustomer studies have been used to investigate whether customers receive counselling in accordance with the standard's basic level. ${ }^{9}$

\section{Occasional services delivered with temporary funding}

In 2005-06, several policy papers highlighting the need to focus on adherence to medicines were published. ${ }^{10,11}$ The Medication Reimbursement Committee report led to a parliamentary decision to allocate DKK 10 million (EUR 1.33 million) annually over a period of four years to adherence research. ${ }^{12}$ During the first years (2005-2007) of the existence of this fund - known popularly as the 'adherence pool' - special emphasis was placed on (dis)continuing medicine treatment and particularly vulnerable groups. The invitation for applications in 2009 focused on how to increase adherence and on studies regarding dose-dispensing systems. To support appropriate decision-making and prioritizing in the funding programme, The Danish Institute for Rational Pharmacotherapy (IRF) published two reports, one on the concept of adherence and problems with non-adherence ${ }^{13}$ and one on 
evidence for adherence interventions. ${ }^{14}$ IRF also frequently publishes reviews and meta-analyses relevant to the adherence area. ${ }^{15}$ Pharmacy projects supported by grants from this programme are shown in Table 1. About half of all the projects take or have taken place in a primary health care setting.

Since the 1990s, the Association of Danish Pharmacies has organized common "theme years" (such as diabetes, asthma, patient safety, better use of medicines) in all community pharmacies. ${ }^{16,17}$ In 2007, a specific adherence campaign was included, and in 2008 adherence and concordance were the common theme of all campaigns. For a description of tools developed for the theme years, see Table 2.

\section{Funded and/or mandated routine services (focusing on adherence)}

At national drug policy level, a number of ITsupported medicine administration systems that facilitate adherence to treatment have been implemented. These include automated dosedispensing in primary care, personal medication profiles, a national prescription server, health portals with information on medicines, a national database on interactions and interaction-checking facilities for patients and professionals.

In 2001, Denmark adopted legislation to implement automated dose-dispensing (ADD) (which is defined as the filling of a medication into a dose container adapted to the specific use of the medication at a

\begin{tabular}{|c|c|c|}
\hline & Setting & Project title \\
\hline 2005 pool & $\begin{array}{l}\text { Pharmakon, The Danish College of } \\
\text { Pharmacy Practice }\end{array}$ & Better medicine use in home care and in nursing homes \\
\hline 2006 pool & $\begin{array}{l}\text { The Faculty of Pharmaceutical Sciences, } \\
\text { University of Copenhagen }\end{array}$ & $\begin{array}{l}\text { 1. Optimal medicine use among ethnic minority Danes. } \\
\text { 2. Evaluation of the health economics aspects of individually } \\
\text { optimizing the medicine use of asthmatics via text messaging } \\
\text { - a controlled study }\end{array}$ \\
\hline \multirow[t]{2}{*}{2007 pool } & $\begin{array}{l}\text { The Faculty of Pharmaceutical Sciences, } \\
\text { University of Copenhagen }\end{array}$ & $\begin{array}{l}\text { Medisam - a collaborative model for medication reviews and } \\
\text { coordination between patients, physicians and pharmacists }\end{array}$ \\
\hline & Community pharmacy & $\begin{array}{l}\text { Community pharmacy-based pharmaceutical care programme } \\
\text { for improving the adherence of elderly poly-pharmacy patients }\end{array}$ \\
\hline
\end{tabular}

\begin{tabular}{|c|c|}
\hline Counselling at the counter: & $\begin{array}{l}\text { 2007: Adherence in general as one of four campaigns } \\
\text { - 2008: Adherence and concordance as an overall theme in all four } \\
\text { campaigns: } \\
\circ \quad \text { Lipid lowering drugs } \\
\circ \quad \text { Chronic Obstructive Pulmonary Disease } \\
\circ \quad \text { Reminder techniques } \\
\circ \quad \text { Depression }\end{array}$ \\
\hline Marketing activities & $\begin{array}{l}\text { - } \quad \text { Newspaper national advertising } \\
\text { - } \quad \text { Window display } \\
\text { - } \quad \text { Great Reminder Day", including badges and free dosing aids (2007) }\end{array}$ \\
\hline Materials and tools for the public & $\begin{array}{l}\text { Introduced in 2007: } \\
\text { - } \quad \text { Brochure: "Medication Safety" } \\
\text { - } \quad \text { Customer card: "Did you remember your medicines?" } \\
\text { - } \quad \text { Free text message reminder service } \\
\text { - } \quad \text { Adherence information on customer computers in pharmacies } \\
\text { Introduced in 2008: } \\
\text { - Brochure: "Reminder techniques" } \\
\text { - Menu card: "Reminder techniques and dosing aids" } \\
\text { Patient Interview or Self assessment tool: "How are you doing with your } \\
\quad \text { medicines?" }\end{array}$ \\
\hline Learning resources for staff & $\begin{array}{l}2007 \\
\text { - Training leaflet: "Communication about adherence" } \\
2008 \text { Dialogue tool for adherence communication } \\
\text { - } \quad \text { PowerPoint presentations and patient cases } \\
\text { - } \quad \text { Adherence and concordance booklet }\end{array}$ \\
\hline Cognitive services featured & $\begin{array}{ll} & \text { Medication review } \\
\text { - } & \text { Medication check (brown bag service) } \\
\text { - } & \text { Dose dispensing } \\
\text { - } & \text { Peak flow measurement } \\
\text { - } & \text { Medication review in nursing homes }\end{array}$ \\
\hline
\end{tabular}
pharmacy or hospital dispensary $)^{18}$ as a national 
system to support correct medicine-taking in primary care. ADD can be ordered from all pharmacies, and is the adherence service most extensively provided by Danish pharmacies (more than 40,000 users in 2008). ${ }^{19}$ The service is provided mainly to elderly poly-pharmacy patients and requires collaboration with other health care professionals.

In 2004, the Personal Medication Profile (PEM) was launched on the national health website www.sundhed.dk as a facility for all Danish residents. The profile gives individual medicine users, general practitioners (GPs), pharmacists and, from 2009, primary care nurses, an overview of medicines bought by patients. The data quality of dosing information is still not optimal in the PEM, though, often resulting in adherence profiles of poor quality. ${ }^{20}$ However, the PEM is a valuable tool for medication reviews and, after system improvements, will have definite potential as an adherence support tool. ${ }^{21}$ The PEM is now being developed into an integrated medication record. ${ }^{22}$

More than $70 \%$ of prescriptions in Denmark are dispensed as e-prescriptions, and, since 2007, physicians have been able to send e-prescriptions either to a pharmacy or to a national prescription server, from which all pharmacies can download them. In principle, pharmacies can check whether prescribed medicines have been collected, thus enabling follow-up on primary non-adherence.

Since 1991, pharmacies in Denmark have been required to offer a generic substitute unless the physician has marked the prescription 'No Substitution'. The system has generated substantial savings for the national health insurance system and patients, but is also criticized for its potentially negative impact on adherence and safety. ${ }^{23,24}$ In small pharmacy-based projects, $20-44 \%$ of patients report that they sometimes find substitution confusing. ${ }^{25,2}$

A so-called "sms-service" has been offered by Danish Pharmacies since 2007. The service was introduced during the theme years as a text message reminder service for adherence support and is now offered as part of patient counselling or nationwide via the website www.apoteket.dk.

Since April 2005 the government has reimbursed an inhaler technique assessment service, the first reimbursed cognitive service in Denmark, which aims at optimizing inhalation techniques. Every pharmacy is required to provide the service. Between May 2006 to April 2007, Danish pharmacies provided the service approximately 40,000 times. $^{27}$ The service is feasible ${ }^{28}$ and has resulted in a reduction of inhalation errors by $80 \%{ }^{29}$

\section{Extended services funded or mandated (focused on adherence)}

Danish pharmacists can offer patients a consultation comprising a medication review, a patient interview and follow-up as the basis for a pharmaceutical care service to optimize patient therapy outcomes. The service targets polypharmacy patients. The service requires collaboration with the patient's GP if the pharmacist recommends therapy adjustments. Research has documented the cost-effectiveness and benefit of the service for patient health and adherence. ${ }^{30-32} \mathrm{~A}$ pharmacist consultation takes about 75 minutes and is currently paid for by the customer (at a price of approximately EUR 50). Data on number of services delivered are not published.

A medication check can be offered by Danish pharmacies. Customers bring their medicines to the pharmacy to check which should be discarded and to get advice on use and storage. The service is estimated to take 20-30 minutes and is currently paid for by the customer (approximately EUR 1520). Data on number of services delivered are not published.

Danish pharmacies offer four services to nursing homes: medication review, dose-dispensing, quality assurance and staff training, the quality of which has been documented in research projects. ${ }^{33-35}$ Although the service package perspective is broader than adherence, it focuses on the appropriate implementation of regimens including dose-dispensing and prevention of medication errors.

\section{Pharmacist and pharmaconomist training in adherence}

Denmark has only one institution, the Faculty of Pharmaceutical Sciences (University of Copenhagen) that confers an MSc degree in pharmacy. In 2008, the Faculty had 1,100 bachelor's and master's students and $110 \mathrm{PhD}$ students. About 70 students attend one of the Faculty's three continuing education master's programmes (Master in Industrial Drug Development, Master in Pharmaceutical Regulatory Affairs or Master in Drug Management).

Pharmacy students learn about adherence issues in several courses during their bachelor's and master's programmes (see Table 3), during their six-month pharmacy internship and during an elective course on quality-assured medicine use. Overall, the courses deal with patient adherence definitions, models and theories on adherence, methods for identifying non-adherence, strategies to improve adherence and the economic consequences of nonadherence.

During the pharmacy internship, students can join a research project in which adherence is studied and analysed - the 'Medisam study', which is further described in the research section below. ${ }^{36,37}$ It is founded on the belief that pharmacy practice research, pharmacy practice and student learning are closely connected and interwoven.

The pharmaconomist education is a three-year programme consisting of practical training periods and eight theoretical courses. ${ }^{38}$ Concordance and adherence theory of is taught in the third course during the first year, by assignments in the practical training period and, later on, during multidisciplinary courses. 


\section{Post-graduate programmes}

The Master in Drug Management (MDM) programme deals with adherence issues. The programme aim is to ensure the quality of drug utilization in society and to increase patient safety. The MDM programme is a one-year degree programme for pharmacists and others with a health care-related background. The programme offers six compulsory courses (30 European Credit Transfer System credits (ECTS), where one ECTS corresponds to 27-28 student working hours). All courses (except for the leadership course) include adherence-related issues. Students can also opt to include adherence issues in their final thesis, a solution chosen by all three students (in pharmacy) who have completed the programme to date..$^{39-41}$

In 2007 a certificate programme for Danish pharmaconomists was established - "Postgraduate education in clinical pharmacy and public health"with a total of 30 ECTS corresponding to six months full-time study to be completed over a period of two to six years. The programme comprises five courses, two of which (clinical pharmacy and pharmacotherapy) have adherence and behaviour change as major subjects, and participants are trained in motivational interviewing and selfmanagement enhancement.

\section{Continuing education}

In Denmark, there are no mandatory requirements for continuing education, but the pharmacy has to keep documentation of staff qualifications for inspection and quality audits. Most professional continuing education programmes for pharmacists and pharmaconomists are offered by or in collaboration with Pharmakon. Many two-day courses in pharmacotherapy are offered in relation to theme years, and these include the pharmacy's role in detecting and resolving adherence problems.

\section{Research in adherence to medication treatment}

Adherence research has been part of Danish pharmacy practice since the late 1970s. Most research has been based on qualitative methods (interviews) and conducted from the Royal Danish School of Pharmacy (later the Faculty of Pharmaceutical Sciences, University of Copenhagen). Research has been based on the theory that medicine users' own perspectives must be included when describing and trying to understand medication adherence and nonadherence, and that non-adherence is not necessarily 'bad' and/or due to the patient's forgetfulness. ${ }^{42-44}$ Since the 1970 s many research projects have thus dealt with users' everyday experience with medicines (such as perceptions of medicine, adherence, reasons for being adherent/non-adherent). ${ }^{45-58}$ Most pharmacists have also conducted such studies on a small scale as part of their education. ${ }^{59}$ In recent years this body of knowledge has supported the shift from an adherence to a concordance orientation and strongly influenced pharmaceutical care projects in Denmark, for instance to put even greater focus on patient empowerment.

\begin{tabular}{|c|c|c|c|}
\hline Degree (year) & Course & Content & Assessment \\
\hline Bachelor (1) & $\begin{array}{l}\text { Introductory pharmacy course - } \\
\text { one-hour lecture and four-hour } \\
\text { pharmacy visit }\end{array}$ & $\begin{array}{l}\text { Definition of compliance/adherence, patient } \\
\text { perspectives on medicine use }\end{array}$ & $\begin{array}{l}\text { Report, presentation and } \\
\text { exam }\end{array}$ \\
\hline Master (1) & $\begin{array}{l}\text { Social Pharmacy course }- \text { three } \\
\text { hours followed by report writing }\end{array}$ & $\begin{array}{l}\text { Definition of compliance and adherence, user } \\
\text { perspective on drug utilization, rational } \\
\text { pharmacotherapy, drug-related problems, patient } \\
\text { autonomy. } \\
\text { Students carry out interviews or do a survey with } \\
\text { patients and/or health care professionals on } \\
\text { adherence issues }\end{array}$ & Synopsis and written exam \\
\hline Master (2) & $\begin{array}{l}\text { Pharmacy internship - six } \\
\text { months including two weeks of } \\
\text { theory lectures and class room } \\
\text { teaching in the Faculty - approx. } \\
\text { one week on adherence-related } \\
\text { issues }\end{array}$ & $\begin{array}{l}\text { Definition of adherence, patient empowerment, } \\
\text { communication theory and skills, drug-related } \\
\text { problems, medication reviews, motivational } \\
\text { interviewing, patient interviews (students watch two } \\
\text { interviews in the auditorium - with a patient and } \\
\text { with a person who needs motivation - and carry out } \\
\text { patient interviews themselves in a patient's home) }\end{array}$ & Written port-folio exam \\
\hline Master (3) & $\begin{array}{l}\text { Elective course in Quality } \\
\text { Assurance of Drug Therapy (18 } \\
\text { lectures and } 21 \text { class-room } \\
\text { sessions each lasting } 3 \text { hours) }\end{array}$ & $\begin{array}{l}\text { The aim of the course is to give the student insight } \\
\text { into clinical pharmaceutical activities in the primary } \\
\text { health care sector; to provide insight into quality } \\
\text { assurance of drug therapy; to enhance the } \\
\text { students' understanding of drug-related problems, } \\
\text { adverse drug reactions, drug-related morbidity and } \\
\text { other unintended drug reactions; and to focus on } \\
\text { patient safety aspects (medication errors, etc.) } \\
\text { Adherence issues are dealt with throughout the } \\
\text { entire course. }\end{array}$ & $\begin{array}{l}\text { Reports, oral presentation } \\
\text { and defence }\end{array}$ \\
\hline $\begin{array}{l}\text { Post-graduate } \\
\text { programme }\end{array}$ & $\begin{array}{l}\text { Master in Drug Management - } \\
\text { six 40-hour courses }\end{array}$ & $\begin{array}{l}\text { Courses deal with approaches to and theories on } \\
\text { pharmaceuticals in health care, leadership in health } \\
\text { care, project planning in health care, clinical } \\
\text { pharmacy and pharmacotherapy, counselling in } \\
\text { medicine use and evaluation and documentation of } \\
\text { medicine use. }\end{array}$ & $\begin{array}{l}\text { Reports or } \\
\text { presentations }\end{array}$ \\
\hline
\end{tabular}


After the late 1990s, a shift was experienced in Danish community pharmacy adherence research from the small, qualitative studies mentioned above to larger quantitative, controlled studies carried out under the auspices of two interdisciplinary research centres, The Research Centre for Quality in Medicine Use (FKL) based at the Faculty of Pharmaceutical Sciences (www.fkl-center.dk) and The Apofarma Consortium (www.apofarma.dk). FKL was launched in September 1999 and is an umbrella entity that addresses research needs by analysing associations between medicine use and the population's health, health behaviours and socio-economic conditions; by exploring users' experiences, assessments and strategies in medicine use; and by providing interventions in health care aimed at optimizing medicine use. Several studies on medication adherence in a primary setting are operated from the FKL platform. The following is a description of the largest and most influential studies and initiatives.

Therapeutic Outcomes Monitoring (TOM) and medication review

The first Danish study on pharmaceutical care was carried out in the mid-1990s in collaboration with Charles D. Hepler's team at the University of Florida. Like research done by the other countries in the Pharmaceutical Care Network Europe (PCNE), it offered major insights into the development of a disease-specific pharmaceutical care model with strong emphasis on the user perspective. The study also paved the way for the establishment of the first third-party paid cognitive service in Danish community pharmacies in $2004 .^{60}$ The TOM study on asthma was followed by another PCNE-based research programme entitled 'Improving Drug Therapy for the Elderly' in which a generic pharmaceutical care model was developed and tested. $^{31}$ Both projects showed positive health outcomes as well as cost-effective benefits.

\section{Safe and Effective Use of Medicines}

This research programme comprised projects that developed and tested adherence-enhancing interventions and estimated the frequency of adherence problems among users of antihypertensives and anti-diabetics in a Danish community setting. ${ }^{1,61,62}$ A community pharmacist provided the extensive intervention and a pharmaconomist in the same pharmacy delivered the basic intervention.

The interventions were multidimensional and based on individual patient needs. The intervention model included a concordance-based partnership between patient, pharmacy staff and general practitioner. The programme elements and solutions were: quick screening for non-adherence and identification of problem types, patient story-telling, finding resources in the patient system, patient education, individual coaching and counselling, offers of relevant reminder technology, medication review and follow-up.

The hypertension project included 240 patients and showed that both interventions significantly affected patient-perceived effects on symptoms, blood pressure, knowledge, drug use, health-related quality of life (HRQoL) and satisfaction. The diabetes project included 80 patients and showed positive patient-perceived effects on symptoms, blood pressure, blood glucose, knowledge, drug use, adherence and HRQoL, and quantifiable effects on the pharmacists' measurements of blood pressure, blood glucose and cholesterol.

\section{The Pharmacy-University study}

The Pharmacy-University study ${ }^{36,37,63-65}$ was a large three-year programme that used research in the 100 internship pharmacies as a strategy for learning and researching in the pharmacy. The overall aim of the programme was to contribute to the quality development of pharmacy practice and pharmacy practice research in the area of pharmaceutical care services. The programme involved researchers, pharmacy students, pharmacy staff, and more than 450 patients (patients with angina pectoris, asthma or type 2 diabetes). It focused on patient's adherence, comparing questionnaire data from more than 1,500 pharmacy staff concerning their beliefs about patient's medication adherence with patient's own description of medication adherence. Data from patients were collected in individual home-based qualitative interviews with the patients. The study showed that one fifth of the angina pectoris patients, almost a third of the type 2 diabetes patients and half of the asthma patients used their medicine inappropriately, the majority of which being non-adherence. ${ }^{36}$

\section{The Medisam study}

In 2008 the internship pharmacies and the university launched a new three-year study, the Medisam study, as a model that patients, general practitioners and pharmacists could use for collaborating on medication review and medication reconciliation. In 2009, 118 type 2 diabetes patients participated, and were interviewed on various issues, including adherence, by pharmacy interns in 24 internship pharmacies throughout Denmark. This study is currently in progress and results have not been published yet.

\section{Automated dose-dispensing}

A review showed that there is no evidence that the automated dose-dispensing (ADD) system alone increases adherence or has any health-related effects. ${ }^{66}$ Interestingly, eight out of nine patients who received ADD-packed medicine were nonadherent in various ways, with intentional nonadherence being the most frequent type of behaviour. ${ }^{67}$

\section{The Helping Hand}

A recent study evaluated a new adherence reminding device named 'The Helping Hand'. A main finding was that the Helping Hand can improve self-reported adherence among hypertensive patients, mainly in newly diagnosed patients by $6 \%$ or in patients starting a new medication treatment. Blood pressure, though, was not influenced by the device. ${ }^{68}$ 


\begin{tabular}{|c|c|}
\hline Table 4. Apofarma's adherence technology programme: 'Adherence technologies - technology perspective' \\
\hline$\cdot$ Measuring adherence \\
Medicine profiles \\
Reminder technologies \\
$0 \quad$ Text messaging \\
$0 \quad$ Telephone reminders \\
$0 \quad$ MEMS and automatic dispensing machines \\
$0 \quad$ Individual memory systems \\
Dose-dispensed medicine \\
$0 \quad$ Check for adverse effects, automated dose-dispensing \\
$0 \quad$ Dose packaging \\
Intelligent medicine packaging \\
Devices for correct medicine use, e.g. \\
$0 \quad$ Inhalation technique \\
$0 \quad$ Injection technique \\
Diaries $\quad$ Own and internet-based \\
$0 \quad$ E-based patient training \\
Biofeedback \\
$0 \quad$ Blood pressure \\
$0 \quad$ Blood sugar \\
$0 \quad$ Cholesterol \\
.$\quad$
\end{tabular}

Optimal medicine use among ethnic minority Danes

In this study, 12 ethnic minority pharmacists conducted medication reviews and interviews with 26 ethnic minority patients speaking the pharmacist's mother tongue. The study identified drug-related problems (including adherence problems), suggested solutions to GPs and mapped patients' drug-related experiences, perceptions and actions. About $65 \%$ of the patients did not adhere to their GP's advice on how to use medicines, 38\% used medicines prescribed to others and $54 \%$ used medicines bought in their country of origin. ${ }^{69,70}$

Transfer of research to practice

The Apofarma Consortium was established in 2007 between the Faculty of Pharmaceutical Sciences, the University of Copenhagen, Pharmakon and the Association of Danish Pharmacies. Its vision is to catalyse a quick process 'from research to consumer' in the area of medicine use and practice development. The consortium's vision and mission are realized through innovative programmes. Especially, programme $\mathrm{C}$ on 'Compliance technologies - technology perspective' (see Table 4 ) is particularly relevant in relation to adherence because it involves testing and evaluating technologies to strengthen adherence.

\section{CONCLUSIONS AND FUTURE PERSPECTIVES}

In conclusion, our analysis has documented that Danish pharmaceutical education and research has focused strongly on adherence to treatment for more than three decades. Adherence initiatives in Danish community pharmacies have developed substantially in the past five to ten years. This development can be expected to continue in future years, and follow the professional, ethical, and customer-oriented visions in the pharmacy strategy laid down in 2007. Development of professional IT systems is another high-priority area, as is counselling for e-pharmacy.

In the future, the following public health areas can be expected to focus on adherence-related activities: chronic conditions, mental illness, elderly patients, poly-pharmacy patients, nursing homes, home care, dose-dispensing, use of patient educators, counselling and coaching, dose dispensing and other adherence support technology, medication review, sector transitions, medication reconciliation along with more interdisciplinary collaboration and cooperation with regional and local authority administrations and health centres and patient organisations.

\section{CONFLICT OF INTEREST}

There are no conflicts of interest.

\section{References}

1. Herborg H, Haugbølle LS, Sørensen L, Rossing C, Dam P. Developing a generic, individualised adherence programme for chronic medication users. Pharm Pract. 2008;6(3):148-157.

2. WHO. Adherence to long-term therapies - evidence for action. Noncommunicable diseases and mental health adherence to long term therapies project. Report. Geneva: World Health Organisation; 2003.

3. The Nordic Pharmacy Association. The Added Value of Nordic Pharmacies. Documentation examples. A report from the Nordic Working Group on Professional Responsibility in Pharmacy (PAPA). The Nordic Pharmacy Association February 2008.

4. Dam $\mathrm{P}$, Herborg $\mathrm{H}$, Rossing C. Evidensrapport 9 - Interventioner til forbedring af compliance og concordance $\mathrm{i}$ forbindelse med lægemiddelbehandlinger - Version 2.1. [Evidence report 9 - Interventions for improving compliance and concordance in relation to drug treatment - In Danish]. Report. Pharmakon 2008. 
5. Agergaard M, Rossing C, Herborg H. Evidens for Apotekets Rådgivning [Evidence for pharmacy counselling. Report. In Danish]. Rapport. Version 1.1. 2009. Pharmakon.

6. The Danish Pharmaceutical Association. The annual reports of the Danish Association of Pharmacies. URL: http://www. apotekerforeningen.dk (Accessed September 29, 2009)

7. Chronic Conditions - Patient, Healthcare and Community. Summary and recommendations. National Board of Health, Denmark, April 2006. URL:

http://www.sst.dk/Planlaegning\%20og\%20kvalitet/Kronisk\%20sygdom\%20og\%20foroebsprogrammer.aspx, (Accessed 22 October 2009)

8. Dansk Selskab for Patientsikkerhed. Strategi 2007-2010 for Dansk Selskab for Patientsikkerhed [Strategy for the Danish Society for Patient Safety 2007-2010.In Danish]. www.patientsikkerhed.dk/om_selskabet/strategi/, 2009 (Accessed October 21, 2009).

9. Thomsen MH, Bolvig T, Damsø LB, Fonnesbæk L, Herborg H. Pseudo customers in Danish Pharmacies. World Congress of Pharmacy and Pharmaceutical Sciences, 68th Congress of FIP, Basel, Switzerland 3-4 September 2008. (abstract and poster)

10. Kortlægning af praksis for medicinering i den kommunale hjemmepleje [Mapping of medication practice in local authority home care. Report. In Danish] Den digitale taskforce \& Devoteam Fischer \& Lorenz A/S, September 2003. www.modernisering.dk/fileadmin/user_upload/documents/Udsyn/Danske_rapporter/Medicinering_bilag2_kommunal_hje mmesygepleje.pdf. (accessed 22 October 2009)

11. Brug medicinen bedre - Perspektiver i klinisk farmaci. Rapport fra Lægemiddelstyrelsens arbejdsgruppe om klinisk farmaci juni 2004 [Use medicine better - perspectives in clinical pharmacy. Report from the working group on clinical pharmacy. In Danish. Danish Medicines Agency, June 2004]

www.laegemiddelstyrelsen.dk/publikationer/netpub/rapporter/brug_medicin_bedre/index.htm. (Accessed on October 21 2009)

12. Committee on Medicine Reimbursement. Medicine reimbursement and correct use of medicine. Report. Copenhagen. 2004.

13. Institut for Rationel Farmakoterapi [Institute for Rational Pharmacotherapy]. Compliance - om afvigelser mellem lægers ordinationer og patieternes aktuelle medicinindtag.[Compliance - about deviations between prescribing and actual medicine use. Report. In Danish]. Rapport, April 2006.

14. Lindberg M. Compliance: Hvilke interventioner virker? Foreliggende evidens ud fra randomiserede undersøgelser [Which interventions are effective? Evidence from randomised trials. Paper. In Danish]. Institut for Rationel Farmakoterapi, juni 2008. www.dkma.dk/1024/visUKLSArtikel.asp?artikellD=15132 (accessed 22 October 2009)

15. Institut for Rationel Farmakoterapi. Metaanalyse - Ingen klinisk forskel på kopipræparater og originalpræparater [Metaanalysis - no clinical difference between generic products and original products. In Danish] www.irf.dk/dk/anmeldelser/studieanmeldelser/metaanalyse_ingen_klinisk_forskel_paa_kopipraeparater_og_originalprae parater_03.htm

16. The Association of Danish Pharmacies. Annual Report. www. apotekerforeningen.dk (Accessed September 29, 2009) Report 2006-2007

17. The Association of Danish Pharmacies. Annual Report. www. apotekerforeningen.dk (Accessed September 29, 2009) Report 2007-2008

18. Lægemiddelstyrelsen. Lægemiddelbekendtgørelse $\mathrm{nr}$. 80 af 04/02/2003. Bekendtgørelse om dosisdispensering af lægemidler [Danish Medicines Agency. Executive order no. 80 of 4 February 2003 on dose dispensing of drugs. In Danish]. 2003.

19. Herborg H, Haugbølle LS, Lee A. Automated Dose Dispensing in Danish Primary Health Care: a Technology under Construction. Pharm Pract. 2008;6(2):103-112.

20. Andersen LS, Sørensen L, Haugbølle LS. Anvendelighed af den personlige elektroniske medicinprofil (PEM) til beregning af patienters compliance med lægemiddelbehandlingen [Using the personale electronic medication profile (PEM) for calculating medication compliance - In Danish]. Marts 2009, Ugeskrift for Læger: 899-903.

21. Dydensborg CB, Krabbe T. Komplians hos hypertensionspatienter undersøgt ved hjælp af medicinprofilen på sundhed.dk [Compliance among hypertensive patients investigated by the personale electronic medication profile on sundhed.dk. Paper. In Danish]. Ugeskrift for Læger 2007;169:4347-50.

22. National Strategy for Digitalization of the Danish Healthcare Service 2008-2012. Digital Health 2007. www.sdsd.dk/ /media/Files/Strategi/Strategy_english.ashx (accessed 22 October 2009)

23. Rubak SLM, Andersen MLE, Mainz J et al. Hvordan vurderer praktiserende læger lægemiddelsubstitutionsordningen? [How do general practitioners assess the generic substitution scheme? - In Danish]. Ugeskr Læger 2000; 162: 6070-3

24. Rubak SLM, Andersen MLE, Mainz J et al. Hvordan vurderer apotekere og farmaceuter lægemiddelsubstitutionsordningen? [How do pharmacy owners and community pharmacists assess the generic substitution scheme? - In Danish]. Ugeskrift for Læger 2000; 162: 6074-7

25. Rossing C, Sørensen L, Herborg H. Adherence problems among type 2-diabetics. Abstract and poster for PCNE working conference. Gothenburg 2007. www.pharmakon.dk/pages/Apotek.aspx?PagelD=147, (accessed 22 October 2009).

26. Dam P, Rossing C. Afdækning af kunders holdning til og erfaringer med substitution [Mapping customer's attitude towards and experiences with substitution. Presentation. In Danish]. Temauge for Apotekerne i Ribe Sønderjyllandskredsen. Pharmakon 2007. www.pharmakon.dk/data/files/Aps/Konsulentopgaver/Substitution_rapport_web.pdf (Accessed 22 October 2009)

27. Kaarill L, Børsting A, Dyssegaard A, Fonnesbæk L: Inhalation Technique Assessment. The first health service in Danish pharmacies reimbursed by the government. Abstracts 2000, World Congress of Pharmacy and Pharmaceutical Sciences 2005:98. 
28. Klinke B, Fonnesbæk L. Tjek på inhalation - afprøvning af ydelsen [Inhaler technique service - testing the service. Evaluation report. In Danish]. Evalueringsrapport. Danmarks Farmaceutiske Universitet og Pharmakon 2005.

29. Herborg H, Soendergaard B, Froekjaer B, Fonnesbaek L, Jorgensen T, Hepler CD, Grainger-Rousseau TJ, Ersboell BK. Improving drug therapy for patients with asthma. Part 1: Patient outcomes. J Am Pharm Assoc. 2001;41:539-550.

30. Bernsten C, Björkman I, Caramona M, Crealey G, Frøkjaer B, Grundberger E, Gustafsson T, Henman M, Herborg H, Hughes C, McElnay J, Magner M, van Mil F, Schaeffer M, Silva S, Søndergaard B, Sturgess I, Tromp D, Vivero L, Winterstein A; Pharmaceutical care of the Elderly in Europe Research (PEER) Group. Improving the Well-Being of Elderly Patients via Community Pharmacy-Based Provision of Pharmaceutical Care: A Multicentre Study in Seven European Countries. Drugs Aging. 2001;18(1):63-77.

31. Søndergaard B, Herborg H, Jørgensen T, et al. Forebyggelse af lægemiddelrelaterede problemer gennem Apotekets ÆEldre Service. Et forsøgsprojekt på danske apoteker 1996-1999 [Prevention of drug-related problems via phamacy based elderly service. A pharmacy project 1996-1999. Report. In Danish]. Report 2001.

32. Søndergaard B, Thorleifsson S, Herborg H, Frøkjær B, Hepler CH, Ersbøll BK. Kvalitetssikring af astmapatienters lægemiddelbehandling. Sundhedsøkonomisk analyse [Quality assuring astma patient's medications - a health economic analysis. Paper. In Danish]. Ugeskrift for Læger 2000; 162: 480-6.

33. Pultz K, Salout M. Ydelsen "Medicingennemgang på plejehjem og i hjemmeplejen" afprøvet på 5 plejehjem [The service 'Medication review at nursing homes and in home care' tested at 5 nursing homes. Evaluation report. In Danish]. Pharmakon and Association of Danish Pharmacies. 2003

34. Glintborg D, Bonnichsen B. Bedre medicinsk behandling af ældre på plejehjem og i hjemmeplejen [Improved medical treatment of elderly in nursing homes and local authority home care. Report. In Danish]. Forebyggelsesrådet $\mathrm{i}$ Frederiksborg Amt.

www.sundhed.dk/Fil.ashx?id=1164\&ext=pdf\&navn=2008_09_12_Vejledning_sundheddk_2_udgave_juli_2008_endelig_ udgave.pdf. December 2006.

35. Pultz K, Søndergaard B, Herborg H. Farmaceutisk rådgivning til plejehjem [Pharmaceutical counselling at nursing homes. Evaluation report. In Danish]. Evalueringsrapport 2003.

36. Haugbølle LS, Sørensen EW. Drug-related problems in patients with angina pectoris, type 2 diabetes and asthma results from interviewing the patients at home. Pharm World Sci. (2006);28:239-247.

37. Sørensen EW; Haugbølle LS. Using an action research process in pharmacy practice research: A cooperative project between university and internship pharmacies. Res Soc Admin Pharm. 2008;4(4):384-401.

38. Education of Pharmaconomists..www.pharmakon.dk/pages/International.aspx?PagelD=152 (Accessed 17 October 2009)

39. Gram-Hansen M. Rådgivning på APOTEK - en undersøgelse af forbrugernes forventninger til apotek og til apotekets faglige rådgivning [Counselling in pharmacy - a study of user expectation to pharmacy and pharmacy counselling. Master thesis. In Danish], masterprojekt 2007, Det Farmaceutiske Fakultet, Københavns Universitet.

40. Kristoffersen ITS. Medicingennemgang i Ny Thisted Kommune - et udviklingsprojekt [Medication review in Ny Thisted Municipality. Master thesis. In Danish], masterprojekt 2007, Det Farmaceutiske Fakultet, Københavns Universitet.

41. Agerholm H. Udvikling af apoteket ved registrering af lægemiddelrelaterede problemer - Et aktionsforskningsprojekt [Development of pharmacy by registrering drug-related problems - an action-research project. Master thesis. In Danish]. masterprojekt, 2006, Danmarks Farmaceutiske Universitet.

42. Larsen B O, Hansen EH. The Active Medicine User. Scand J Prim Health Care. 1985;3:55-59.

43. Hansen EH, Launsø L, Morgall J. Samarbejde mellem brugeroraganisationer \& apoteksfarmaceuter om lægemiddelanvendelse - arbejdsrapport [Cooperation between user organisations and community pharmacists concerning medication use. Working report - In Danish], Institut for Samfundsfarmaci 1989.

44. Hansen EH, Launsø L. Experiments with Collaboration between Patient Associations and Pharmacists. Acta Pharmaceutica Suecica 1986;(suppl 1):163-173.

45. Almarsdóttir AB, Björnsdóttir I, Traulsen JM. A lay prescription for tailor-made drugs - focus group reflections on pharmacogenomics. Health Policy. 2005;(71):233-241.

46. Hansen $\mathrm{EH}$. Technology assessment in a user perspective - experiences with drug technology. Int $\mathrm{J}$ Tech Assess Health Care 1992;8:150-165.

47. Knudsen P, Hansen EH, Traulsen JM. Perceptions of young women using SSRI antidepressants - a reclassification of stigma. Int J Pharm Pract. 2002:10:243-252

48. Haugbølle LS, Devantier K. Frydenlund B. A user perspective on type-1 diabetes: sense of illness, search for freedom and the role of the pharmacy. Patient Educ Couns. 2002:47:361-368.

49. Haugbølle LS, Sørensen EW, Gundersen B, Lorentzen L, Petersen KH. Basing pharmacy counselling on the perspective of the angina pectoris patient. Pharm World Sci. 2002;24(2):71-78.

50. Møldrup, C. Hansen, RR. Danes' acceptance of drug use for non-disease conditions. Curr Med Res Opin. 2006;22(4):777-780.

51. Møldrup C. No cure, No pay - consumer / patient perspective. J Med Mark 2006;6(1):31-37.

52. Nielsen L, Møldrup C. Lay perspective on pharmacogenetics and application of this in future drug treatment - a Danish quantitative survey. 26,3,309-325, 2007.

53. Nørgaard LS, Laursen M, Lassen S. Knowledge, attitudes and polydrug use among Ecstacy users - a London study. J Soc Admin Pharm 2001; 18 (2): 51-58.

54. Nørreslet M, Larsen JB, and Traulsen JM. The medicine user - Lost in translation? Analysis of the official political debate prior to the deregulation of the Danish medicine distribution system. Soc Sci Med 2005;61:1733-1740.

55. Rehne J, Møldrup, C. Danes' awareness of and attitude towards direct-to-consumer advertising (DTC-A) of prescription drugs. A quantitative survey of 3000 respondents. J Med Mark. 2007;8(1):31-38. 
56. Traulsen JM, Almarsdóttir AB. Pharmaceutical policy and the lay public. Pharm World Sci. 2005:27:273-277.

57. Traulsen JM, Björnsdóttir I, Almarsdóttir AB. "I'm happy if I can help" - public views on future medicines and gene therapy in Iceland. Community Genetics. 2008;(11):2.

58. Traulsen JM, Almarsdóttir AB, Björnsdóttir I. The lay user perspective on the quality of pharmaceuticals, drug therapy and pharmacy services. Pharm World Sci. 2002;24(5):196-200.

59. Herborg H, Sørensen EW, Frøkjær B. Pharmaceutical Care in Community Pharmacies: Practice and Research in Denmark. Ann Pharmacother. 2007;41:681-689.

60. Herborg H, Soendergaard B, Joergensen T, Fonnesbaek L, Hepler CD, Holst H. Improving drug therapy for patients with asthma. Part II: Use of antiasthma medication. J.Am Pharm Assoc. 2001; 41:551.9.

61. Herborg H, Dam P, Rossing C, Sørensen L. Safe and Effective Use of Oral Antidiabetic Drugs: A Controlled Study of an Adherence-enhancing Intervention. Abstract and poster for FIP Congress, Basel 2008

62. Herborg H, Sorensen L, Rossing C. Safe and effective use of antihypertensives: A controlled study of adherence enhancing interventions. Abstract and poster for FIP Congress, Beijing 2007

63. Haugbølle LS, Sørensen EW, Gundersen B, Lorentzen L, Petersen KH. Basing pharmacy counselling of the perspective of the angina pectoris patient. Pharm World Sci. 2002;24(2):71-78.

64. Haugbølle LS, Sørensen EW, Herborg $\mathrm{H}$. The perspective of the angina pectoris patient: medication- and illness-related factual knowledge, perceptions and behaviour. Patient Educ Couns. 2002;47:281-289.

65. Sørensen EW, Herborg H, Haugbølle LS, Tomsen D. Improving situated learning in pharmacy internship. Pharm Educ. 2005;5(3/4):223-234.

66. Søndergaard B, Rossing C, Haugbølle LS, Lee A. Litteraturstudie af dosisdispensering som medicinsk teknologi [Literature review of dose-dispensing as a heath technology. Working report. In Danish]. Arbejdsrapport. 2005. Danmarks Farmaceutiske Universitet, Pharmakon, Syddansk Universitet, ISBN 87-90923-64-2.

67. Larsen AB, Haugbølle LS. The impact of an automated dose-dispensing scheme on user compliance, medication understanding, and medication. Research in Social and Administrative Pharmacy 2007; 3: 265-284.

68. Christensen A. Electronic monitoring of patient adherence in hypertension- Survey and clinical assessments of a reminder and monitoring device. PhD thesis, Copenhagen University, 2009.

69. Haugbølle LS; Søndergaard B, Morgall J. et al. Optimal lægemiddelanvendelse blandt ikke-etniske danskere (del 2) Gennemførelse af medicingennemgang [Optimal drug use amont non-ethnical Danes (Part 2) - Medication reviews. In Danish].Københavns Universitet. Rapport. Det Farmaceutiske Fakultet. Marts 2009 ISBN 978-87-92199-55-3.

70. Hoffman T. Indvandere importerer lægemidler[Immigrants import medicine - In Danish] 29. September 2009. Available from http://www.videnskab.dk/content/dk/samfund/indvandrere_importerer_lagemidler

\section{Welcome to the $16^{\text {th }}$ ISPW!}
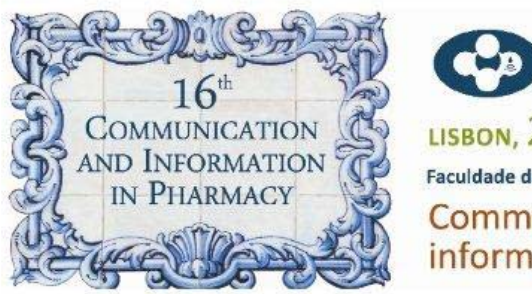

LISBON, 23rd $/ 26^{\text {th }}$ AUGUST 2010

Faculdade de Farmácia da Universidade de Lisboa

Communication and

information in pharmacy

This is a preliminary short announcement for the $16^{\text {th }}$ ISPW

Host Institution and Venue

Faculty of Pharmacy, University of Lisbon, Portugal

Dates

$23^{\text {rd }}$ to $26^{\text {th }}$ August 2010

Key note Speakers and further information soon to be announced at

www.ff.ul.pt/16ISPW

For any inquiries, please use the following email address: 16 ISPW@ff.ul.pt

Hope to have you here in Summer 2010! 